\title{
Obsidian balls (marekanite) from Cerro Tijerina, central Nicaragua: petrographic investigations
}

\author{
Štěpánka MRÁZOVÁ1* ${ }^{*}$ Petr GADAS² \\ ${ }^{1}$ Czech Geological Survey, Klárov 3, 11821 Prague 1, Czech Republic; stepanka.mrazova@geology.cz \\ 2 Joint Laboratory of Electron Microscopy and Microanalysis, Department of Geological Sciences, Masaryk University, Kotlářská 2, \\ 61137 Brno, Czech Republic \\ * Corresponding author
}

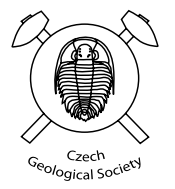

The paper describes a find of volcanic glass in central Nicaragua. We investigated obsidian samples in perlite from a large profile of volcanic rocks (Cerro Tijerina) in the vicinity of the town of Matagalpa. The obsidian occurs in the form of up to 3-cm dark-coloured balls (spheres) randomly distributed in brittle grey perlite, which also has spherulitic texture. These balls, previously called marekanite, are characterised by an abundance of microphenocrysts (feldspar, biotite, amphibole, apatite and magnetite). Microprobe analysis of the homogenous glass of obsidian balls and perlite has confirmed their subalkaline, and particularly high-K calc-alkaline character $\left(\mathrm{SiO}_{2} \geq 70 \%, \mathrm{Na}_{2} \mathrm{O}+\mathrm{K}_{2} \mathrm{O}<\mathrm{Al}_{2} \mathrm{O}_{3}\right)$, which is typical of rhyolitic melts. A sharp contact was observed between the core and the surface layer (approx. 0.1-0.2 mm) of the obsidian balls, reflecting changes in the $\mathrm{H}_{2} \mathrm{O}$ content.

Keywords: obsidian, marekanite, volcanic glass, Cerro Tijerina, Nicaragua

Received: 9 November 2010; accepted: 21 March 2011; handling editor: R. Skála

\section{Introduction}

Obsidian is a volcanic acidic glassy rock associated with perlite. The latter is a grey bulky volcanic rock of similar chemical composition, but with fluidal texture and numerous concentric cracks resembling fragments of pearls. The obsidian balls (spheres) occurring in perlite, usually smaller than $5 \mathrm{~cm}$ in diameter and having an indented surface, are called marekanite. They received their name after the place where they were first discovered, Marekanka near Okhotsk in Siberia, Russia (Judd 1886). Another term for spherically shaped obsidians, used especially by mineral collectors and gemmologists, is "Apache tears". The obsidian balls, differing from the surrounding perlite by a lower water content (Johannsen 1932; Ljunggren 1960), are coloured in various shades, most commonly from smoke-grey to black.

Perlite is formed from volcanic glasses of dacitic and rhyolitic composition by hydration and alteration, i.e., by a change in the mineralogy and texture due to the action of hot or cold aqueous solutions or gases. These processes are caused by meteoric water rather than by the water-rich original magma (Friedman and Smith 1958; Friedman et al. 1966). However, a controversy exists concerning the parameters of perlite formation (diffusion coefficient of water, activation energy of hydration) (Friedman et al. 1966; Marshall 1961). The degree of perlitization also depends on the total volatile contents and temperature (Denton et al. 2009). The alteration of perlitized obsidian was shown to result in the dissolution of glass and crystallization of secondary minerals (smectite, zeolite), as well as in a change in the colour from dark grey to green or dull brown (Noh and Boles 1989; Denton et al. 2009).

The objective of this paper is to describe the petrographic characteristics of the obsidian balls found, for the first time, in the volcanic area of Nicaragua. The finding of obsidian in Nicaragua so far consisted in block-shaped material or Indian tools made of obsidian brought from other regions of Central America.

\section{Geological setting}

The investigated area is located in central Nicaragua, which is built mainly by Palaeogene calc-alkaline volcanic rocks - lavas and extensive acid-intermediate ignimbrites. The main volcanic phase took place in Oligocene, when numerous rhyolite calderas were formed.

The Cerro Liquidámbar volcanic group, named after its dominant peak (1375 m a.s.1.) (N 12 $2^{\circ} 58^{\prime} 17.48^{\prime \prime}$; W $\left.85^{\circ} 59^{\prime} 24.99^{\prime \prime}\right)$, was investigated in detail as a part of a regional study carried out by the Czech Geological Survey (Hradecký et al. 2002). It is located NW of the town of Matagalpa (Fig. 1). The Cerro Tijerina ridge (1 $375 \mathrm{~m}$ a.s.l.) is a dominant feature of the volcanic group.

The rock types and their succession were characterized in a profile (Fig. 2) on the south-eastern slopes of the Cerro Tijerina Massif - Cerro El Ocote, rising from 

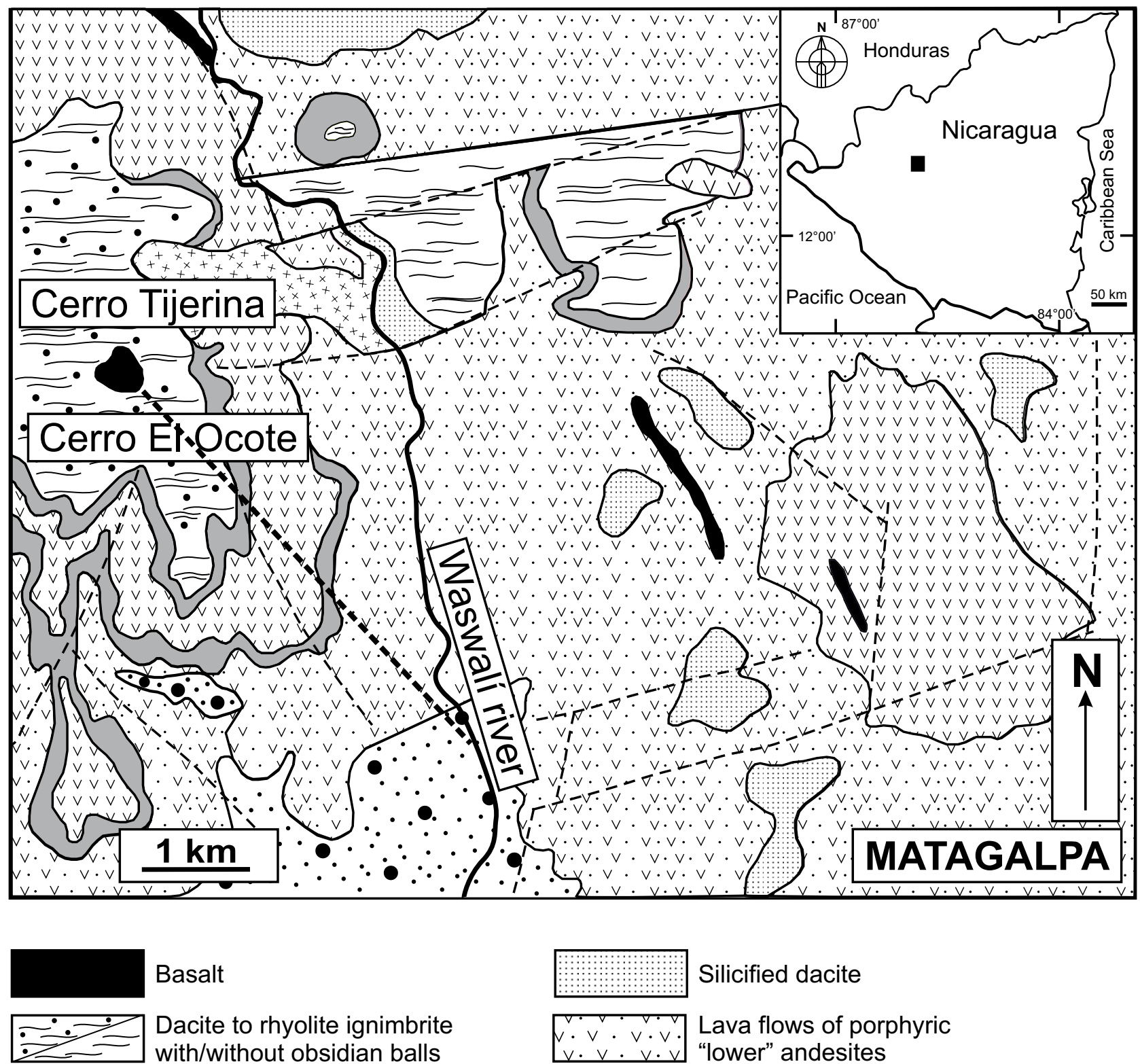

Basalt

Dacite to rhyolite ignimbrite with/without obsidian balls

Rhyolite lavas

Andesite ignimbrite

Lava flows of andesites

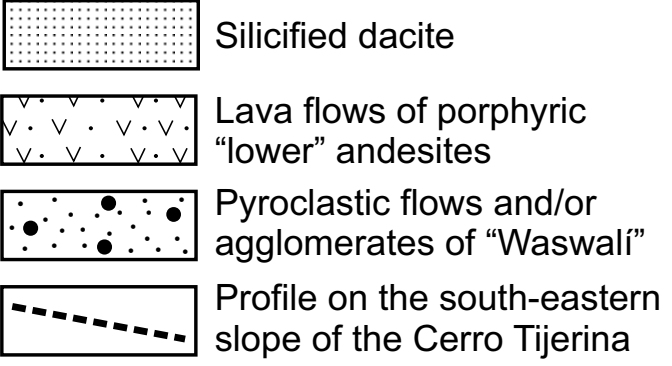

slope of the Cerro Tijerina

$\vee \vee \vee \vee \vee \vee$
$\vee \vee \vee \vee \vee \vee V$

$\vee \vee \vee \vee \vee \vee$

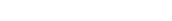

Fig. 1 Geological sketch map of the Cerro Liquidámbar volcanic group.

the Waswali river valley up to the summit. In total, seven layers were distinguished.

1. The base of the profile is formed by coarse-grained pyroclastic flows and/or agglomerates of the so-called "Waswalí" type. The pyroclastic flows are typically of yellow-green colour and consist of layers containing angular and subangular fragments of altered andesites with a size up to $0.4 \mathrm{~m}$, often cross-cut by fine-grained basaltic dykes.

2. The "Waswali'" volcanoclastics are extensively covered by layers of medium-grained porphyric lower andesites, with tabular or spheroidal jointing and lateritic weathering on their top, with a total thickness of up to $220 \mathrm{~m}$. 
3. A layer of fine-grained andesitic ignimbrites with a fluidal texture, up to $20 \mathrm{~m}$ thick, was found on the southern slope of Cerro El Ocote, whereas towards the north they wedge out or terminate on tectonic dislocations.

4. The andesite ignimbrites are covered by younger, andesite to basaltic andesite lava flows that pass upwards to autoclastic breccia. These lava flows are up to $30 \mathrm{~m}$ in thickness. The autoclastic breccia is porphyric, fine to medium grained, formed by clasts of variable sizes with vesicular or compact texture. It has very frequently undergone lateritic weathering. The compact lava flows that typically display tabular jointing are covered by a massive complex of ignimbrites.

5 . The lower ignimbrite layer, up to $30 \mathrm{~m}$ in thickness, is formed by a red-coloured andesite ignimbrite which is finegrained to compact, very often silicified, with well-developed fluidal texture, containing elongate microcrystalline aggregates of quartz and cristobalite. The upper part of the red andesite ignimbrite is locally rheomorphically deformed with the next ignimbrite layer, which probably has dacitic composition and is strongly silicified. Both rocks form an extensively rheomorphically folded complex up to $40 \mathrm{~m}$ in thickness. No andesite ignimbrites were found above this andesite-dacite complex.

6 . The uppermost part of the massive ignimbrite complex is built by silicified, dacite to rhyolite ignimbrites and rhyolite lavas up to $220 \mathrm{~m}$ in thickness. This layer is formed by fine-grained to breccia-type ignimbrites with grey perlite formations of spherulitic texture, containing balls (up to $2 \mathrm{~cm}$ in diameter) of black obsidian - marekanite (Fig. 3 ), chalcedony, devitrified glass and scarce microphenocrysts (feldspar, biotite, amphibole, apatite, magnetite).

7. The top of Cerro Tijerina is formed by the relict of lava flows of strongly altered, vesicular basalt.
Altered vesicular basalt

Dacite to rhyolite ignimbrite

Rhyolite lavas

Fine-grained to breccia-type dacite ignimbrites with grey perlite containing the balls of black obsidian and devitrified glass

Rheomorphically folded complex of andesite and dacite ignimbrite

Fine-grained red-coloured andesite ignimbrite with fluidal texture

Andesite to basaltic andesite lava flows passing upwards to autoclastic lava

Fine-grained andesite ignimbrite with fluidal texture

Lava flows of medium-grained porphyric andesites, with tabular or spheroidal jointing and lateritic weathering on top

Dykes of fine-grained basalt

Coarse-grained pyroclastic flows and/or agglomerates of "Waswali"

Waswalí river 


\section{Methods}

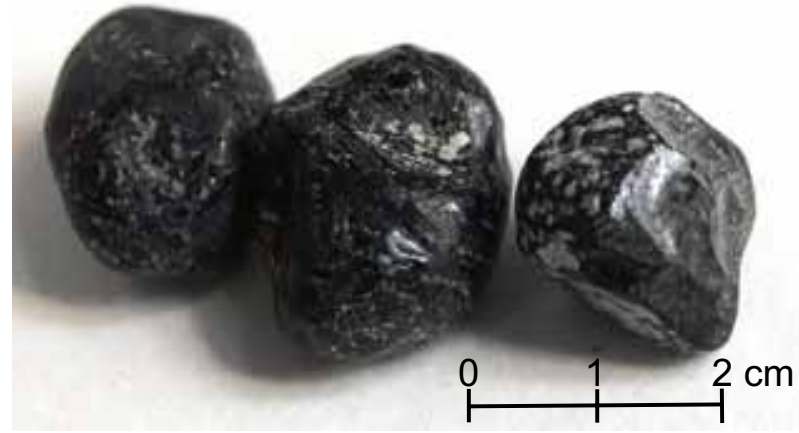

Fig. 3 Photograph of obsidian balls (marekanite).
The chemical analyses of minerals were performed on a CAMECA SX100 electron microprobe at the Joint Laboratory of Electron Microscopy and Microanalysis, Department of Geological Sciences, Masaryk University and the Czech Geological Survey in Brno equipped with a wavelength dispersive spectrometer. The following conditions were used: accelerating voltage of $15 \mathrm{kV}$, probe current of $10 \mathrm{nA}$ and defocused beam of $5 \mu \mathrm{m}$ diameter. The range of counting times was 10-20 s for major elements and $20-40 \mathrm{~s}$ for minor and trace elements. The following standards and analytical $\left(\mathrm{K}_{\alpha}\right)$ lines were used: almandine $\left(\mathrm{Fe}^{2+}, \mathrm{Si}\right)$, wollastonite $(\mathrm{Si})$, grossular $(\mathrm{Al}, \mathrm{Ca})$, $\mathrm{MgO}(\mathrm{Mg})$, sanidine $(\mathrm{K})$, titanite (Ti), spessartine $(\mathrm{Mn})$, $\mathrm{NaCl}(\mathrm{Cl})$, fluorapatite $(\mathrm{Ca}, \mathrm{P})$, topaz $(\mathrm{F})$, baryte $(\mathrm{Ba})$; $\left(\mathrm{L}_{\alpha}\right)$ lines: $\mathrm{CePO}_{4}(\mathrm{Ce}), \mathrm{LaPO}_{4}(\mathrm{La})$ and $\left(\mathrm{L}_{\beta}\right)$ lines: benit-

Tab. 1 Electron-microprobe data of glass from obsidian balls and perlite (wt. \%)

\begin{tabular}{|c|c|c|c|c|c|c|c|c|c|c|c|c|}
\hline Sample No. & $\begin{array}{c}\text { SM1-1C } \\
1\end{array}$ & $\begin{array}{c}\text { SM1-1C } \\
2\end{array}$ & $\begin{array}{c}\text { SM1-1C } \\
3\end{array}$ & $\begin{array}{c}\text { SM1-1C } \\
4\end{array}$ & $\begin{array}{c}\text { SM1-1C } \\
5\end{array}$ & $\begin{array}{c}\text { SM1-1C } \\
6\end{array}$ & $\begin{array}{c}\text { SM1-1C } \\
7\end{array}$ & $\begin{array}{c}\text { SM1-2C } \\
8\end{array}$ & $\begin{array}{c}\text { SM1-2C } \\
9\end{array}$ & $\begin{array}{c}\text { SM1-2C } \\
10\end{array}$ & $\begin{array}{c}\text { SM1-2C } \\
11\end{array}$ & $\begin{array}{c}\text { SM1-2C } \\
12\end{array}$ \\
\hline $\mathrm{SiO}_{2}$ & 76.316 & 77.166 & 77.303 & 75.409 & 76.415 & 76.533 & 77.305 & 76.526 & 76.701 & 76.630 & 77.613 & 77.201 \\
\hline $\mathrm{TiO}_{2}$ & 0.160 & 0.155 & 0.134 & 0.189 & 0.140 & 0.160 & 0.156 & 0.148 & 0.141 & 0.164 & 0.174 & 0.127 \\
\hline $\mathrm{Al}_{2} \mathrm{O}_{3}$ & 13.034 & 12.598 & 12.909 & 12.472 & 12.894 & 12.848 & 12.898 & 12.881 & 12.892 & 13.023 & 12.984 & 12.993 \\
\hline $\mathrm{FeO}$ & 0.582 & 0.376 & 0.747 & 0.677 & 0.767 & 0.825 & 0.862 & 0.704 & 0.776 & 0.697 & 0.253 & 0.499 \\
\hline $\mathrm{MnO}$ & 0.063 & b.d.1 & b.d.1 & b.d.1 & b.d.1 & b.d.1 & b.d.1 & b.d.1 & b.d.1 & 0.114 & 0.095 & b.d.1 \\
\hline $\mathrm{MgO}$ & 0.150 & 0.120 & 0.131 & 0.139 & 0.149 & 0.167 & 0.194 & 0.183 & 0.150 & 0.159 & 0.045 & 0.095 \\
\hline $\mathrm{aOO}$ & 0.793 & 0.807 & 0.781 & 0.865 & 0.797 & 0.798 & 0.865 & 0.831 & 0.837 & 0.825 & 0.782 & 0.721 \\
\hline $\mathrm{Na}_{2} \mathrm{O}$ & 3.142 & 3.315 & 3.040 & 2.599 & 3.510 & 2.943 & 3.428 & 3.539 & 3.333 & 3.291 & 3.250 & 3.140 \\
\hline $\mathrm{K}_{2} \mathrm{O}$ & 4.357 & 4.476 & 4.349 & 4.294 & 4.343 & 4.365 & 4.347 & 4.444 & 4.366 & 4.487 & 4.470 & 4.378 \\
\hline $\mathrm{BaO}$ & 0.082 & b.d.1 & 0.135 & 0.158 & 0.077 & 0.11 & 0.083 & 0.163 & 0.148 & 0.159 & 0.105 & 0.158 \\
\hline $\mathrm{P}_{2} \mathrm{O}_{5}$ & b.d.1 & 0.042 & b.d.1 & b.d.l & 0.027 & b.d.1 & b.d.1 & b.d.1 & 0.035 & 0.023 & b.d.1 & b.d.1 \\
\hline $\mathrm{Cl}$ & 0.087 & 0.058 & 0.059 & 0.092 & 0.081 & 0.089 & 0.074 & 0.106 & 0.080 & 0.086 & 0.070 & 0.069 \\
\hline$\underline{F}$ & 0.086 & 0.106 & 0.053 & 0.022 & b.d.1 & 0.035 & 0.043 & 0.057 & 0.076 & b.d.1 & b.d.1 & b.d.1 \\
\hline Total & 98.884 & 99.289 & 99.689 & 96.991 & 99.302 & 98.986 & 100.277 & 99.646 & 99.598 & 99.692 & 99.903 & 99.447 \\
\hline Sample No. & SM1-2C & SM1-2C & SM1-1C & SM2-C & SM2-C & SM2-C & SM2-C & SM2-C & SM2-C & SM2-C & SM2-C & SM2-C \\
\hline Analysis No. & 13 & 14 & 15 & 16 & 17 & 18 & 19 & 20 & 21 & 22 & 23 & 24 \\
\hline$\overline{\mathrm{SiO}_{2}}$ & 74.989 & 76.198 & 75.061 & 74.858 & 74.681 & 75.202 & 73.787 & 74.176 & 76.801 & 78.494 & 78.945 & 74.860 \\
\hline $\mathrm{TiO}_{2}$ & 0.160 & 0.144 & 0.157 & 0.137 & 0.134 & 0.142 & 0.134 & 0.132 & b.d.1 & b.d.1 & b.d.1 & b.d.1 \\
\hline $\mathrm{Al}_{2} \mathrm{O}_{3}$ & 12.324 & 12.746 & 12.537 & 12.378 & 12.410 & 12.462 & 12.185 & 12.352 & 12.625 & 12.213 & 12.474 & 13.200 \\
\hline $\mathrm{FeO}$ & 0.806 & 0.667 & 0.633 & 0.610 & 0.626 & 0.698 & 0.671 & 0.564 & 0.193 & 0.085 & 0.194 & 0.150 \\
\hline $\mathrm{MnO}$ & 0.071 & 0.062 & b.d.1 & 0.088 & b.d.1 & b.d.1 & b.d.1 & b.d.1 & b.d.1 & b.d.1 & b.d.1 & b.d.1 \\
\hline $\mathrm{MgO}$ & 0.137 & 0.152 & 0.103 & 0.170 & 0.138 & 0.150 & 0.129 & 0.136 & b.d.1 & b.d.1 & b.d.1 & b.d.1 \\
\hline $\mathrm{CaO}$ & 0.791 & 0.755 & 0.731 & 0.824 & 0.845 & 0.801 & 0.792 & 0.783 & 0.428 & 0.228 & 1.877 & 0.282 \\
\hline $\mathrm{Na}_{2} \mathrm{O}$ & 2.916 & 3.142 & 3.080 & 2.719 & 2.297 & 2.474 & 1.310 & 2.280 & 3.544 & 2.849 & 4.894 & 3.175 \\
\hline $\mathrm{K}_{2} \mathrm{O}$ & 4.166 & 4.301 & 4.334 & 4.218 & 4.895 & 4.183 & 4.892 & 4.757 & 4.859 & 5.967 & 0.749 & 6.374 \\
\hline $\mathrm{BaO}$ & 0.109 & 0.082 & 0.076 & 0.048 & 0.224 & 0.126 & 0.085 & 0.111 & 0.942 & 0.372 & 0.165 & 1.180 \\
\hline $\mathrm{P}_{2} \mathrm{O}_{5}$ & 0.053 & b.d.1 & b.d.1 & b.d.1 & b.d.1 & b.d.1 & b.d.1 & 0.029 & b.d.1 & 0.027 & b.d.1 & b.d.l \\
\hline $\mathrm{Cl}$ & 0.071 & 0.079 & 0.117 & 0.071 & 0.067 & 0.065 & 0.085 & 0.086 & b.d.1 & b.d.1 & b.d.1 & b.d.1 \\
\hline$\underline{F}$ & b.d.1 & b.d.1 & b.d.1 & b.d.1 & b.d.1 & b.d.1 & b.d.1 & b.d.1 & b.d.1 & b.d.1 & b.d.1 & b.d.1 \\
\hline Total & 96.619 & 98.377 & 96.937 & 96.196 & 96.448 & 96.407 & 94.219 & 95.498 & 99.482 & 100.373 & 99.433 & 99.313 \\
\hline
\end{tabular}

b.d.l. $=$ below detection limit $\left(\mathrm{all}_{\mathrm{Cr}_{2}} \mathrm{O}_{3}\right.$ values were below detection limit)

Note: Analyses 1-12 - non-hydrated glass from obsidian balls; analyses 13-15 - hydrated rim of obsidian balls; analyses 16-20 - perlite glass; analyses 21-24- spherulite glass 
oite $(\mathrm{Ba})$ and $\mathrm{NdPO}_{4}(\mathrm{Nd})$. The average detection limits and standard deviations (in parentheses) under these conditions were: $\sim 1800 \mathrm{ppm}(0.16)$ for $\mathrm{Nd} ; \sim 1200 \mathrm{ppm}$ (0.13) for $\mathrm{Ba}, \mathrm{La}$ and $\mathrm{F} ; 740 \mathrm{ppm}(0.07)$ for $\mathrm{Ce} ; \sim 700$ ppm (0.64) for $\mathrm{Ca} ; \sim 700 \mathrm{ppm}(0.12)$ for $\mathrm{Na} ; \sim 670 \mathrm{ppm}$ (0.06) for $\mathrm{Mn}$; 500-600 ppm (0.04-0.08) for S and Fe; $\sim 400 \mathrm{ppm}(0.4)$ for $\mathrm{P}$ and $\sim 200-300 \mathrm{ppm}(0.02-0.04)$ for $\mathrm{Si}, \mathrm{Al}, \mathrm{Mg}, \mathrm{K}$ and $\mathrm{Cl}$. The raw data were reduced using PAP matrix corrections (Pouchou and Pichoir 1985). The apatite mineral formula was calculated on basis of 26 anions and a sum of $(\mathrm{F}, \mathrm{Cl}, \mathrm{OH})=2$.

\section{Petrography}

Obsidian balls reaching up to $2 \mathrm{~cm}$ in size (Fig. 3) show macroscopically sharp contact with the surrounding perlite. They are black, non-transparent to semitransparent. When examined by electron microprobe (Tab. 1) the glass appears to be homogeneous except an up to $200 \mu \mathrm{m}$ thick surface layer in contact with the perlite (Fig. 4a). This layer exhibits slightly lower analytical totals of oxides ( 97-98 wt. \%), which is probably due to the elevated content of water. This area also bears signs of corrosion and concentric cracks in places. The surrounding perlite has invariably lower sum of oxides ( 96-96.5 wt. \%) and exhibits compositional homogeneity under BSE. In contrast to the obsidian balls, the perlite contains a large volume (estimated to 10-15 vol. \%) of elongated bubbles, pores up to $0.5 \mathrm{~mm}$ in size, and rare spherulites composed of anhydrous and heterogeneous glass (Fig. 4c). Both the obsidian balls and perlite contain numerous microphenocrysts that differ in quantity and composition. In the perlite, the magnetite, which is up to $10 \mu \mathrm{m}$ in size, is limonitized and subhedral; it occurs with rare anhedral apatite $(<20 \mu \mathrm{m})$, euhedral tabular feldspars $(<10 \mu \mathrm{m})$ and euhedral columnar amphiboles $(<10 \mu \mathrm{m})$. Subhedral magnetite up to $10 \mu \mathrm{m}$ across can be observed in the obsidian balls (Fig. 4b), together with other microphenocrysts that are dispersed very irregularly in the glass. Amphibole microphenocrysts often show subparallel arrangement, thus enhancing the flow texture of the glass (Fig. 4b). Because of the insufficient size of the magnetite, feldspar and amphibole microphenocrysts, only apatite (Fig. 4a) was analysed quantitatively by the electron microprobe (Tab. 2). However, the ED spectra indicated that magnetite has a significant content of $\mathrm{Ti}$, feldspar seems to be an oligoclase with significantly increased $\mathrm{K}$ and the composition of the amphiboles is close to magnesiohornblende.

Rare anhedral apatites up to $20 \mu \mathrm{m}$ across usually occur in the outer parts of the obsidian balls. They are homogenous and exhibit slightly elevated contents of $\mathrm{S}$ (up to $0.048 \mathrm{apfu} ; 0.30$ wt. $\% \mathrm{SO}_{2}$ ), $\mathrm{Mn}$ (up to $0.045 \mathrm{apfu}$
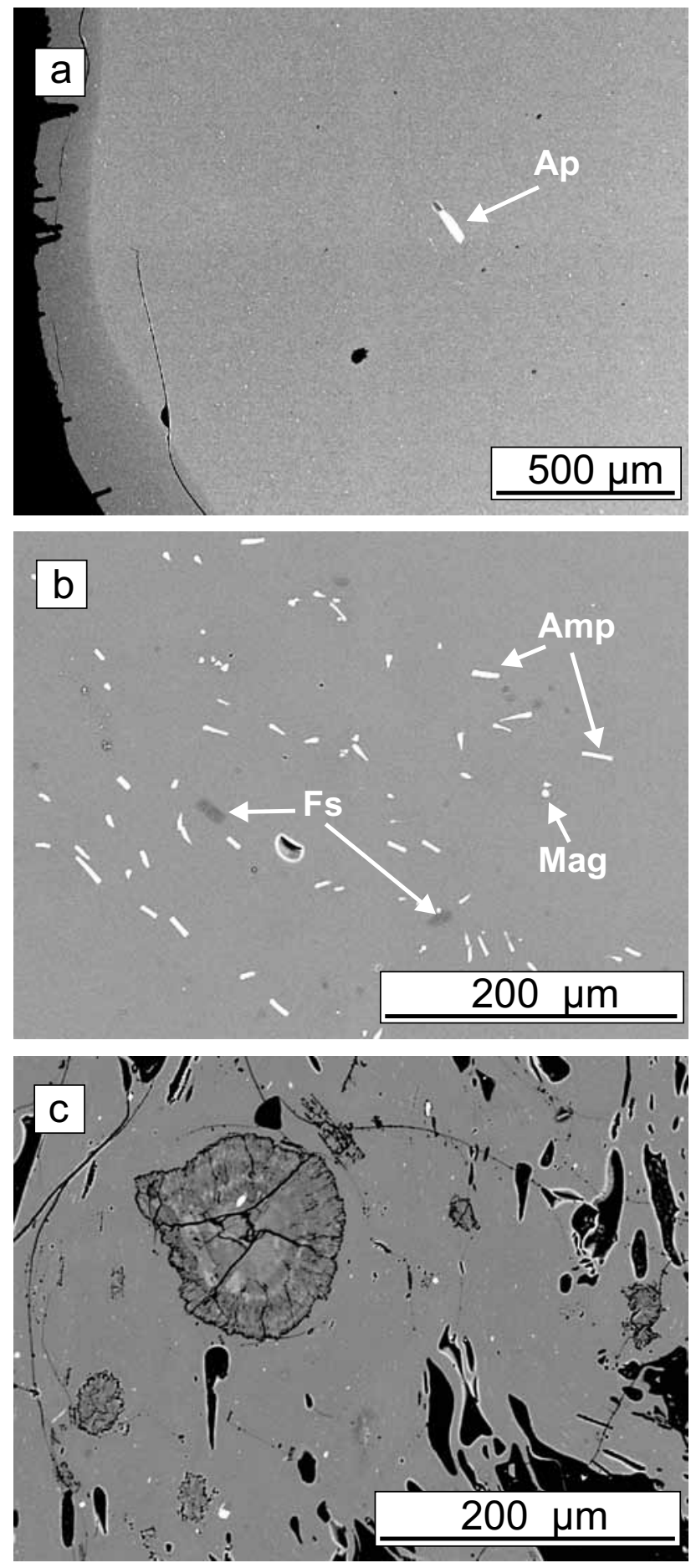

Fig. 4 Obsidian balls and perlite, BSE images. a - Outer part of an obsidian ball with a microphenocryst of apatite; the hydrated, corroded, radially cracked concentric outer shell is darker in colour; $\mathbf{b}$ - Columnar microphenocrysts of feldspar, amphibole and magnetite; $\mathbf{c}$ - Perlite glass rich in bubbles and containing conspicuous spherules.

and 0.31 wt. $\% \mathrm{MnO}), \mathrm{Mg}(0.038$ apfu and 0.15 wt. \% $\mathrm{MgO}$ ), $\mathrm{Fe}^{2+}$ (up to 0.068 apfu; 0.48 wt. \% $\mathrm{FeO}$ ) and REE (up to $0.030 \mathrm{apfu} ; 0.49$ wt. $\%$ of REE oxides). As the fluorine predominates in the $\mathrm{W}$ site $(0.950-1.071 \mathrm{apfu})$, 
Tab. 2 Electron-microprobe data and empirical formulae of apatite microphenocrysts from obsidian balls

\begin{tabular}{|c|c|c|c|}
\hline Sample No. & SM1-1C & SM1-2C & SM1-2C \\
\hline Analysis No. & 1 & 2 & 3 \\
\hline $\mathrm{P}_{2} \mathrm{O}_{5}$ & 40.31 & 41.11 & 41.61 \\
\hline $\mathrm{SiO}_{2}$ & 0.34 & 0.17 & 0.25 \\
\hline $\mathrm{SO}_{2}$ & 0.30 & 0.25 & 0.18 \\
\hline $\mathrm{La}_{2} \mathrm{O}_{3}$ & 0.10 & 0.10 & b.d.l. \\
\hline $\mathrm{Ce}_{2} \mathrm{O}_{3}$ & 0.20 & 0.19 & 0.28 \\
\hline $\mathrm{Nd}_{2} \mathrm{O}_{3}$ & b.d.1. & 0.20 & 0.20 \\
\hline $\mathrm{CaO}$ & 55.52 & 55.57 & 55.18 \\
\hline $\mathrm{FeO}$ & 0.48 & 0.23 & 0.23 \\
\hline $\mathrm{MgO}$ & 0.15 & 0.15 & 0.15 \\
\hline $\mathrm{MnO}$ & 0.31 & 0.28 & 0.25 \\
\hline $\mathrm{Na}_{2} \mathrm{O}$ & 0.24 & 0.16 & 0.09 \\
\hline $\mathrm{K}_{2} \mathrm{O}$ & 0.07 & b.d.l. & 0.06 \\
\hline $\mathrm{F}$ & 1.96 & 2.01 & 1.79 \\
\hline $\mathrm{Cl}$ & 1.49 & 1.43 & 1.38 \\
\hline $\mathrm{H}_{2} \mathrm{O}^{*}$ & 0.46 & 0.46 & 0.59 \\
\hline $\mathrm{O}=\mathrm{Cl}$ & -0.34 & -0.32 & -0.31 \\
\hline $\mathrm{O}=\mathrm{F}$ & -0.83 & -0.85 & -0.75 \\
\hline Total & 100.77 & 101.14 & 101.17 \\
\hline \multicolumn{4}{|c|}{ Calculated on basis of 26 anions and $\sum(\mathrm{F}, \mathrm{Cl}, \mathrm{OH})=2$} \\
\hline $\mathrm{P}$ & 5.789 & 5.862 & 5.909 \\
\hline $\mathrm{Si}$ & 0.058 & 0.029 & 0.042 \\
\hline $\mathrm{S}$ & 0.048 & 0.039 & 0.028 \\
\hline $\mathrm{Ca}$ & 10.091 & 10.028 & 9.917 \\
\hline $\mathrm{Fe}^{2+}$ & 0.068 & 0.032 & 0.032 \\
\hline $\mathrm{Mg}$ & 0.038 & 0.038 & 0.038 \\
\hline $\mathrm{Mn}$ & 0.045 & 0.040 & 0.036 \\
\hline $\mathrm{La}$ & 0.006 & 0.006 & b.d.l. \\
\hline $\mathrm{Ce}$ & 0.012 & 0.012 & 0.017 \\
\hline $\mathrm{Nd}$ & b.d.l. & 0.012 & 0.012 \\
\hline $\mathrm{Na}$ & 0.079 & 0.052 & 0.029 \\
\hline K & 0.015 & b.d.l. & 0.013 \\
\hline $\mathrm{F}$ & 1.052 & 1.071 & 0.950 \\
\hline $\mathrm{OH}$ & 0.520 & 0.521 & 0.658 \\
\hline $\mathrm{Cl}$ & 0.428 & 0.408 & 0.392 \\
\hline
\end{tabular}

* calculated value; b.d.1. = below detection limit

all the apatites correspond to apatite-(F), although they also show significantly elevated $\mathrm{Cl}(0.392-0.428 \mathrm{apfu})$.

The TAS classification diagram (Le Bas et al. 1986) (Fig. 5a) shows that both obsidian and perlite glasses belong to subalkaline series and correspond to rhyolite. However, the content of alkalis in the perlite is far more variable than in the obsidian. The classification diagram according to Peccerillo and Taylor (1976) (Fig. 5b) shows that both glasses are of high-K calc-alkaline composition.
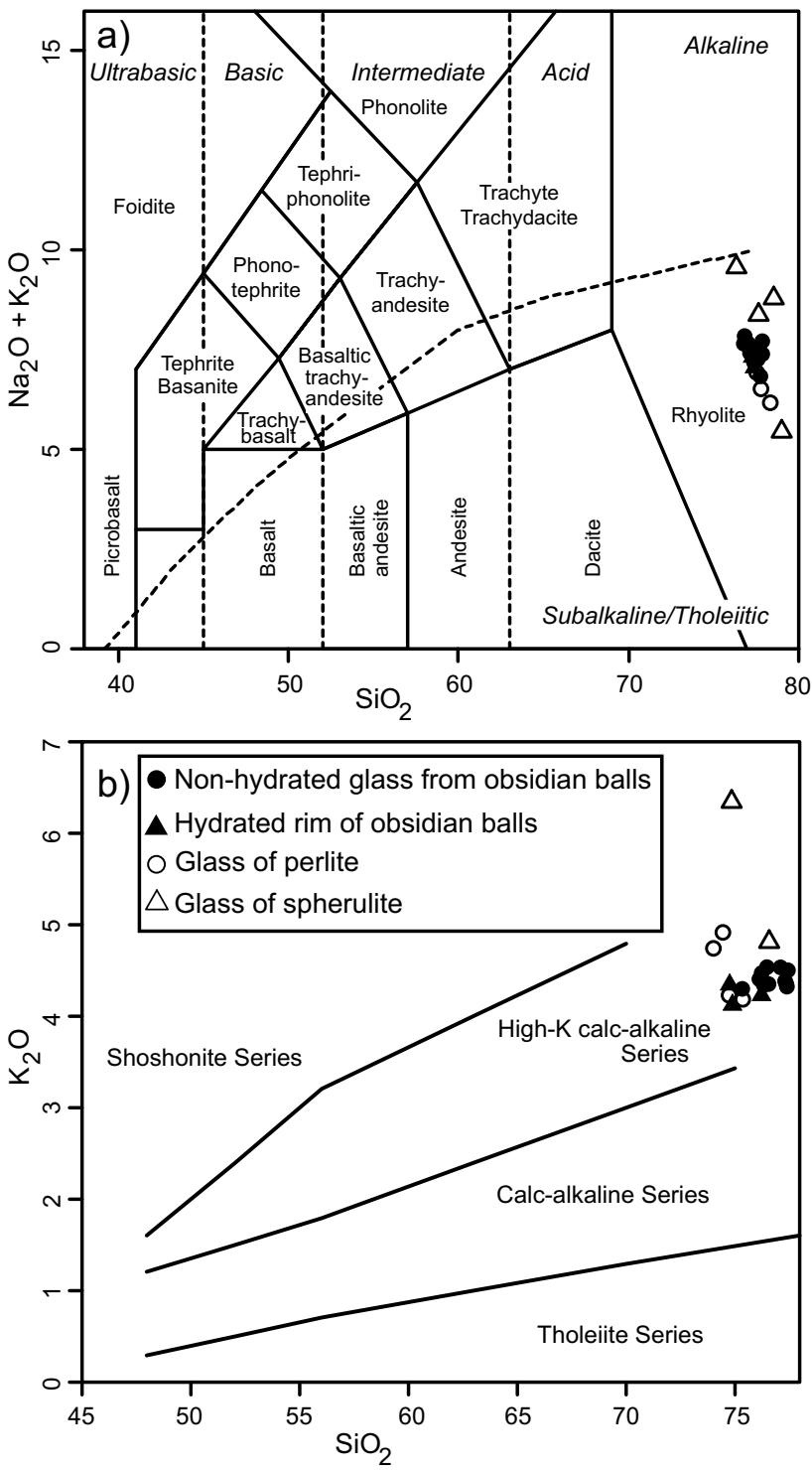

Fig. 5 Classification diagrams $\mathrm{Na}_{2} \mathrm{O}+\mathrm{K}_{2} \mathrm{O}$ versus $\mathrm{SiO}_{2}$ (Le Bas et al. 1986) (a) and $\mathrm{K}_{2} \mathrm{O}$ versus $\mathrm{SiO}_{2}$ (Peccerillo and Taylor 1976) (b) showing that the glass compositions are rhyolitic and high calc-alkaline (full symbols - obsidian, empty symbols - perlite).

\section{Discussion and conclusions}

The results reported in this paper provide evidence that the grey perlite with vesicular texture and the black obsidian glassy balls had a common evolution history. The similar chemical and mineral compositions of the obsidian and perlite glasses indicate their origin from the same silicic melt. The crystals of the minerals observed in both rocks are almost parallel to the lava flow, which indicates their formation before the final lava solidification. The perlite is extremely brittle due to a large number of microscopic cracks, which enables disclosure 
of the obsidian glassy balls (marekanite) when the rock breaks apart.

The electron microprobe study has shown certain yet not fundamental differences in the compositions of the obsidian and perlite glasses. These are mainly caused by hydration of the silicic melt. The differences in content of alkali elements can also be accounted for by the perlite hydration. In comparison with the obsidian, the perlite glass exhibits both higher degree of hydration and higher variability in the contents of alkalis. The glass of both the perlite and the obsidian balls is homogeneous except for a thin outer shell, which indicates the surface hydration of the obsidian. We assume that this hydration took place already in the solid state.

Acknowledgements. We are grateful to Pasquale Acquafredda and an anonymous reviewer and also the Editor-inChief for reviews and suggested improvements. R. Skála is thanked for editorial handling. This research has been financed by the Ministry of the Environment of the Czech Republic in the framework of international cooperation of the Czech Republic and Nicaragua.

\section{References}

Denton JS, Tuffen H, Gilbert JS, Odling N (2009) The hydration and alteration of perlite and rhyolite. J Geol Soc, London 166: 895-904

Friedman I, SMith RL (1958) The deuterium content of water in some volcanic glasses. Geochim Cosmochim Acta 15: 218-228
Friedman I, Smith RL, Long WD (1966) Hydration of natural glass and formation of perlite. Geol Soc America Bull 77: 323-328

Hradecký P, Mlčoch B, Mrázová Š, Rapprich V, Havlíček P, Novák Z, Opletal M, Ševčík J, Vorel T (2002) Geological study of the natural hazards in the area of Matagalpa, central Nicaragua. Czech Geological Survey Prague, INETER Managua, pp 1-110 (in Czech)

Johannsen A (1932) A Descriptive Petrography of the Igneous Rocks. Chicago University Press, Chicago, Illinois, Vol. 2: pp 1-428

JudD JW (1886) On marekanite and its allies. Geol Mag 3: $241-248$

Le Bas MJ, Le Maitre RW, Streckeisen A, Zanettin B (1986) A chemical classification of volcanic rocks on the total alkali-silica diagram. J Petrol 27: 745-750

LJUNGGREN P (1960) A formation of marekanite at El Fiscal, Guatemala. Geol Mag 97: 49-53

Marshall RR (1961) Devitrification of natural glass. Geol Soc America Bull 77: 1493-1520

NoH JH, Boles JR (1989) Diagenetic alteration of perlite in the Guryongpo area, Republic of Korea. Clay Clay Miner 37: 47-58

Peccerillo A, Taylor SR (1976) Geochemistry of Eocene calc-alkaline volcanic rocks from the Kastamonu area, northern Turkey. Contrib Mineral Petrol 68: 61-81

Pouchou JL, Pichoir F (1985) "PAP" $(\varphi-\rho-Z)$ procedure for improved quantitative microanalysis. In: ARMSTRONG JT (ed) Microbeam Analysis. San Francisco Press, pp 104-106 